\title{
Gene Expression, Localization, and Characterization of Endothelin A and B Receptors in the Human Adrenal Cortex
}

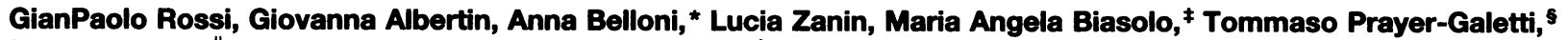 \\ Michael Bader," Gastone G. Nussdorfer, ${ }^{\star}$ Giorgio Palù, ${ }^{\star}$ and Achille C. Pessina \\ Departments of Clinical Medicine, *Anatomy, ${ }^{\ddagger}$ Microbiology, and ${ }^{8}$ Urology University of Padova, Italy; and $"$ MDC for Molecular
} Medicine, Berlin-Buch, Germany

\begin{abstract}
Compelling evidence indicates that the endothelium-derived potent vasoconstrictor endothelin-1 (ET-1) stimulates aldosterone secretion by interacting with specific receptors. Although two different ET-1 receptors have been identified and cloned, the receptor subtype involved in mediating aldosterone secretion is still unknown. Accordingly, we wished to investigate whether the genes of ET-1 and of its receptors $A$ and $B$ are expressed in the normal human adrenal cortex. We designed specific primers for ET-1 and the ET $_{\mathrm{A}}$ and $\mathbf{E T}_{B}$ receptors genes and developed a reverse transcription polymerase chain reaction (RT-PCR) with chemiluminescent quantitation of the cDNA. In addition, we carried out ${ }^{125}$ I ET-1 displacement studies with cold ET-1, ET-3 and the specific $E_{A}$ and $E_{B}$ ligands $B Q 123$ and sarafotoxin $6 C$. Localization of each receptor subtype was also investigated by autoradiography. Binding experiments were first individually analyzed by Scatchard and Hofstee plot and then coanalyzed by the nonlinear iterative curve fitting program Ligand. Histologically normal adrenal cortex tissue, obtained from kidney cancer patients $(n=7)$, and an aldosterone-producing adenoma (APA), which is histogenetically derived from the zona glomerulosa (ZG) cells, were studied. Results showed that the ET-1, ET And $_{A}$ ET $_{B}$ mRNA can be detected by RT-PCR in all adrenal cortices as well as in the APA. The best fitting of the ${ }^{125}$ I ET-1 displacement binding data was consistently provided by a two-site model both in the normal adrenal cortex $(F=22.1, P<0.0001)$ and in the APA $(F=18.4, P<0.0001)$. In the former the density $\left(B_{\max }\right)$ of the $\mathbf{E T}_{A}$ and $\mathbf{E T}_{B}$ subtype was $2.6 \pm 0.5 \mathrm{pmol} / \mathrm{mg}$ protein $(\mathrm{m} \pm \mathrm{SEM})$ and $1.19 \pm 0.6$, respectively. The dissociation constant $\left(K_{d}\right)$ of ET-1, ET-3, S6C, and BQ-123 for each receptor subtype resulted to be within the range reported for human tissue for the $\mathbf{E T}_{A}$ and $\mathbf{E T}_{B}$ receptors. In the APA tissue the $B_{\max }$ tended to be lower (1.33 and $0.8 \mathrm{pmol} /$ mg protein, for the $\mathbf{E T}_{\mathrm{A}}$ and $\mathrm{ET}_{\mathrm{B}}$, respectively) but the $K_{d}$ were similar. Autoradiographic studies confirmed the presence of both receptor subtypes on the $\mathrm{ZG}$ as well as on APA cells. Thus, the genes of ET-1 and both its receptor
\end{abstract}

This study was presented in part at the 15th Scientific Meeting of the International Society of Hypertension, Melbourne March 20-24, 1994.

Address correspondence to GianPaolo Rossi, M.D., F.A.C.C., Hypertension Unit, Clinica Medica 1, University Hospital, via Giustiniani, 2, 35126 Padova, Italy.

Received for publication 7 March 1994

J. Clin. Invest.

(c) The American Society for Clinical Investigation, Inc. 0021-9738/94/09/1226/09 \$2.00

Volume 94, September 1994, 1226-1234 subtypes $\mathrm{ET}_{\mathrm{A}}$ and $\mathrm{ET}_{\mathrm{B}}$ are actively transcribed in the human adrenal cortex. Furthermore, both receptor subtypes are translated into proteins in ZG and APA cells. (J. Clin. Invest. 1994. 94:1226-1234.) Key words: aldosterone • adrenal cortex • endothelin • receptors subtypes • sarafotoxin • antagonists

\section{Introduction}

The secretion of aldosterone is regulated by several factors. The three major secretagogues are angiotensin II, ACTH, and potassium, whereas dopamine, sodium, and the atriopeptins exert an inhibitory effect (1). Recently, the very potent 21 -amino acid vasoconstrictor peptide endothelin-1 (ET-1), ${ }^{1}$ has also been shown to stimulate aldosterone secretion both in vitro and in vivo (2-7), and to enhance ACTH- and. angiotensin IIstimulated aldosterone secretion from cultured bovine adrenal cells $(8,9)$. Furthermore, it has been reported that the chronic infusion of ET-1 raises plasma aldosterone concentration in rats and that isolated zona glomerulosa (ZG) cells from the infused animals showed an enhancement of their basal production of aldosterone, which was consistent with de novo synthesis of the aldosterone-synthesizing enzymes $(10,11)$. Accordingly, it has been hypothesized that ET-1 plays a role in the regulation of aldosterone in several conditions, including liver cirrhosis (12), congestive heart failure $(13,14)$, preeclampsia $(15)$, liver transplantation $(16,17)$, endotoxiemic shock $(18)$, primary and malignant hypertension $(19,20)$, which are characterized by enhanced aldosterone secretion and endothelial damage. Indeed, the latter can turn-on synthesis and secretion of ET-1, and thereby enhance aldosterone secretion through endocrine-paracrine mechanisms. Since the chronic infusion of ET-1, a well known mitogen (10), was found to cause a notable hypertrophy of ZG cells it is also conceivable that ET-1 may be involved in enhancing aldosterone secretion in primary aldosteronism, a rare cause of secondary hypertension where no known stimulus of aldosterone secretion has been identified so far (1).

Two different ET-1 specific receptors, the ET $_{A}$ and ET $_{B}$, which have been identified, pharmacologically characterized, and cloned (21), appear to mediate the physiological effects of ET-1. Autoradiographic evidence of ET-1 specific binding to the adrenal cortex and medulla has been reported in several species (22-26). ET-1 specific binding to the ZG has been consistently identified in rat, porcine and human adrenals (23, 26,27 ), as well as to cultured calf adrenal ZG cells (2). Although the data suggested the presence of two ET-1 receptors

1. Abbreviations used in this paper: APA, aldosterone-producing adenoma; EDRF, endothelium-derived relaxing factor; ET-1, endothelin-1; $\mathrm{RT}$, reverse transcription; S6C, sarafotoxin $6 \mathrm{C}$; ZG, zona glomerulosa; $\mathrm{ZF}$, zona fasciculata. 
(26), no selective endothelin antagonist was available at that time and therefore no conclusive information on whether ET-1 receptor subtypes exist in the adrenal cortex could be gained. In vitro experiments with ET-1, ET-2, ET-3, and the weak ET $_{B}$ agonist sarafotoxin B have thereafter suggested, although not conclusively proven, the presence of a high and a low affinity binding site in cultured calf glomerulosa cells (26). Furthermore, mRNA for both the $\mathrm{ET}_{\mathrm{A}}$ and the $\mathrm{ET}_{\mathrm{B}}$ receptor has been detected by Northern blot analysis by Imai et al. (27) in three human adrenal glands obtained from patients with an aldosterone producing adenoma. However, ET-1 saturation isotherms were consistent with the existence of only one population of ET-1 receptors, suggesting that only one receptor subtype mRNA was effectively translated into protein. Thus, the question on whether endothelin receptor subtypes with possible different functional role exist in the normal human adrenal cortex is still unanswered.

The recent development of the selective antagonist for the $\mathrm{ET}_{\mathrm{A}}$ receptor $\mathrm{BQ123}$ and of the weak $\mathrm{ET}_{\mathrm{B}}$ receptor agonist sarafotoxin $6 \mathrm{C}$ ( $\mathrm{S6C}$ ) has provided new tools for investigating the distribution and pharmacological properties of endothelin receptors. Furthermore, molecular medicine techniques such as the reverse transcription polymerase chain reaction (RT-PCR) allowed investigating genes expression in different organs starting from very limited amount of tissue, such as that available in the clinical setting.

Thus, the purpose of this study was to investigate whether $\mathrm{ET}_{\mathrm{A}}$ and $\mathrm{ET}_{\mathrm{B}}$ receptors are expressed in the normal human adrenal cortex and to assess their anatomical distribution as well as their binding properties. To further establish whether the $\mathrm{ET}_{\mathrm{A}}$ and $\mathrm{ET}_{\mathrm{B}}$ receptors are present in the $\mathrm{ZG}$, an adrenal tumor, the aldosterone-producing adenoma (APA), which is histogenetically derived from ZG cells, was also studied.

\section{Methods}

Preparation of adrenal tissues. Adrenal cortices were obtained from consenting patients undergoing unilateral nephrectomy for kidney cancer $(n=7)$. All adrenals were histologically normal. To rule out the possibility of contamination from the medulla, that is rich in ET-1 binding sites, the utmost care was taken to dissect out only the outer portion of the adrenal cortex. In addition, we studied an APA obtained at surgery from a patient with primary aldosteronism. In this case the surrounding histologically normal cortex and renal cortex biopsy tissue served as controls for the gene expression studies. After excision, tissues were immediately frozen in liquid nitrogen and stored at $-195^{\circ} \mathrm{C}$ until they were used for ET-1 binding studies, nucleic acid extraction, and autoradiography.

Binding study. Samples were homogenized with a Polytron homogenizer in $0.25 \mathrm{M}$ sucrose at $4^{\circ} \mathrm{C}$ and then centrifuged at $11,000 \mathrm{~g}$ for 60 $\mathrm{min}$ at room temperature. The pellets were resuspended in $0.05 \mathrm{M}$ Tris$\mathrm{HCl}$ buffer, $\mathrm{pH} 7.4$, with $5 \mathrm{mM} \mathrm{MgCl} 2,1 \mu \mathrm{M}$ aprotinin, $0.1 \%$ bacitracin, $0.5 \mathrm{mM}$ phenylmethylsulphonylfluoride according to the method of Nguyen et al. (28) with minor modifications. Protein concentration was measured with a Lowry modified method (DC Protein Assay; Bio Rad Laboratories, Milano, Italy). For binding studies, membrane suspensions (15-25 $\mu \mathrm{g}$ protein) were incubated with $25 \mathrm{pM}{ }^{125}$ I ET-1 (Amersham Laboratories, Amersham, Buckinghamshire, U.K.; specific activity $2,000 \mathrm{Ci} / \mathrm{mmol}$ ) in the absence and presence of increasing concentrations of unlabelled ET-1, ET-3, the specific ET $_{B}$ agonist S6C (29) (Sigma Aldrich, Milano, Italy) and the specific $\mathrm{ET}_{\mathrm{A}}$ antagonist $\mathrm{BQ123}$ (Peninsula Laboratories Inc., Merseyside, U.K.). Nonspecific binding was determined in presence of a large amount of unlabeled ET-1 (100 $\mathrm{nM}$ ). Based on previous studies, which have established the time required to attain equilibrium conditions, incubation was carried out for
$2 \mathrm{~h}$ at room temperature $(30,31)$. Total radioactivity was counted in a $\gamma$ counter and the free radioactive ET- 1 was removed by centrifugation. The pellets were washed for three times with the same buffer and then counted. All experiments were carried out in duplicate.

Analysis. The binding experiments were analyzed by the nonlinear iterative curve fitting program LIGAND developed by Munson and coworkers $(32,33)$ (Ligand, Biosoft, Cambridge, U.K.). No correction for the decay of ${ }^{125} \mathrm{I}$ was applied since this has been shown to. cause inappropriately high estimates of $\mathrm{B}_{\max }$ and $K_{\mathrm{d}}$ over time (34). Saturation and competition binding data were analysed using EBDA to obtain Hill coefficients (saturation experiments) and pseudo-Hill coefficients (competition experiments) and LIGAND to obtain preliminary estimates of the dissociation constant $\left(K_{d}\right)$ and receptor density $\left(B_{\max }\right)$ values. Data files were run simultaneously with LIGAND to obtain final parameter estimates. The presence of one, two, or three sites was tested using the F-ratio test in LIGAND. The model adopted was that which provided the significantly best fit $(P<0.05)$.

$R N A$ preparation. Total RNA was isolated either by a modification of the $\mathrm{LiCl}$ (35) or by the guanidium isothiocyanate methods. After isolation, total RNA samples were checked by gel electrophoresis in an $1 \%$ agarose gel stained with $\mathrm{EtBr}$ after denaturation with $6 \mathrm{M}$ glyoxal, $0.25 \mathrm{M}$ DMSO, and $0.1 \mathrm{M} \mathrm{NaH}_{2} \mathrm{PO}_{4}, \mathrm{pH}$ 7.0. The purity of the extracted RNA was also controlled by recording the UV absorbance of each sample between 200 and $300 \mathrm{~nm}$ wavelength; concentrations of total RNA were then calculated by spectrophotometric measurements at 260 $\mathrm{nm}$ wavelength.

Amplification method. For use in the polymerase chain reaction, total RNA was reversely transcribed to cDNA according to Wang et al. $(36,37) .5 \mu \mathrm{g}$ of total RNA was dissolved in $100 \mu \mathrm{l}$ of a mixture containing (final concentration) $1 \mathrm{mM}$ of dATP, dGTP, and dTTP, $\mathrm{dCTP}, 1 \mathrm{U} / \mu \mathrm{l}$ of RNAsin, $2.5 \mu \mathrm{M}$ Random Hexamers, $50 \mathrm{mM} \mathrm{KCl}$, $10 \mathrm{mM}$ Tris- $\mathrm{HCl}, \mathrm{pH} 8.3,5 \mathrm{mM} \mathrm{MgCl}{ }_{2}$, and $2.5 \mathrm{U}$ of cloned Moloney Murine Leukemia Virus reverse transcriptase (M-MLV-RT; GeneAmp RNA PCR Kit; Perkin Elmer, Norwalk, CT). After incubation at $42^{\circ} \mathrm{C}$ for $15 \mathrm{~min}$, temperature was raised to $99^{\circ} \mathrm{C}$ for $5 \mathrm{~min}$ and then reaction mixture tubes were quickly chilled on ice. For amplification of the resulting cDNA, $20 \mu$ l of the reverse transcription mixture were used. The sample volume was increased to $100 \mu \mathrm{l}$ with a solution containing $50 \mathrm{mM} \mathrm{KCl}, 10 \mathrm{mM}$ Tris, $\mathrm{pH} 8.3,2 \mathrm{mM} \mathrm{MgCl}_{2}, 0.02 \mathrm{mM}$ digoxigenindUTP (Boheringer Mannheim, Milano, Italy) and $0.1 \mu \mathrm{M}$ of up- and downstream primers as well as $2.5 \mathrm{U}$ of Taq polymerase (AmpliTaq DNA Polymerase; Perkin Elmer/Cetus). The thermal profile used in a 5600 Perkin Elmer Cetus thermal cycler included a denaturation step at $95^{\circ} \mathrm{C}$ for $1 \mathrm{~min}$, annealing at $54^{\circ} \mathrm{C}$ for $1 \mathrm{~min}$ and extension step at $72^{\circ} \mathrm{C}$ for $1 \mathrm{~min}$ for a total of 36 cycles. An additional extension step at the temperature of $72^{\circ} \mathrm{C}$ for $7 \mathrm{~min}$ was then carried out. The $5^{\prime}$ (upstream) primer for ET-1 consisted of $20 \mathrm{bp}(183-203)$ : AGA GTG TGT CTA CTT CTG CC and the 3' primer of 19 bp (606-625: GCG TTA TGT GAC CCA CAA C) (37). Both the $5^{\prime}$ and $3^{\prime}$ primers used for the human $\mathrm{ET}_{\mathrm{A}}$ gene receptor consisted of 18 bases corresponding to sequences 830-847 (CGC TGA TAG CCA GTC TTG) and 14821499 (CGG TTC TTG TCC ATT TCG), respectively (38). For the $\mathrm{ET}_{\mathrm{B}}$ gene receptor the $5^{\prime}$ primer consisted of 19 bases (511-529: GGA CCC ATC GAG ATC AAG G) and the 3' primer of 21 bases (12511271: AGA ATC CTG CTG AGG TGA AGG) (39).

To assess the kinetics of the PCR amplification reaction 5- $\mu$ laliquots of the PCR products of each gene were collected at each cycle starting from the 19th. As a positive control, amplification of a 838-bp fragment of the human $\beta$-actin gene was carried out in parallel using the following primers: 5' (upstream) 5' ATC TGG CAC CAC ACC TTC TAC AAT GAG CTG CG 3' and 3' (downstream) 5' CGT CAT ACT CCT GCT TGC TGA TCC ACA TCT GC 3' (Clontech Laboratories, Palo Alto, CA). As a further control, RNA from the plasmid pAW109 was reversed-transcribed and amplification of a 308 bp fragment of an IL-1 $\alpha$ site was carried out (GeneAmp RNA PCR Kit, Perkin Elmer). To rule out the possibility of amplifying genomic DNA, in some experiments the PCR was carried out with no prior reverse transcritpion of the RNA.

Detection of mRNA. Detection of the PCR amplification products was first carried out by size-fractionation on $1.5 \%$ agarose gel electro- 


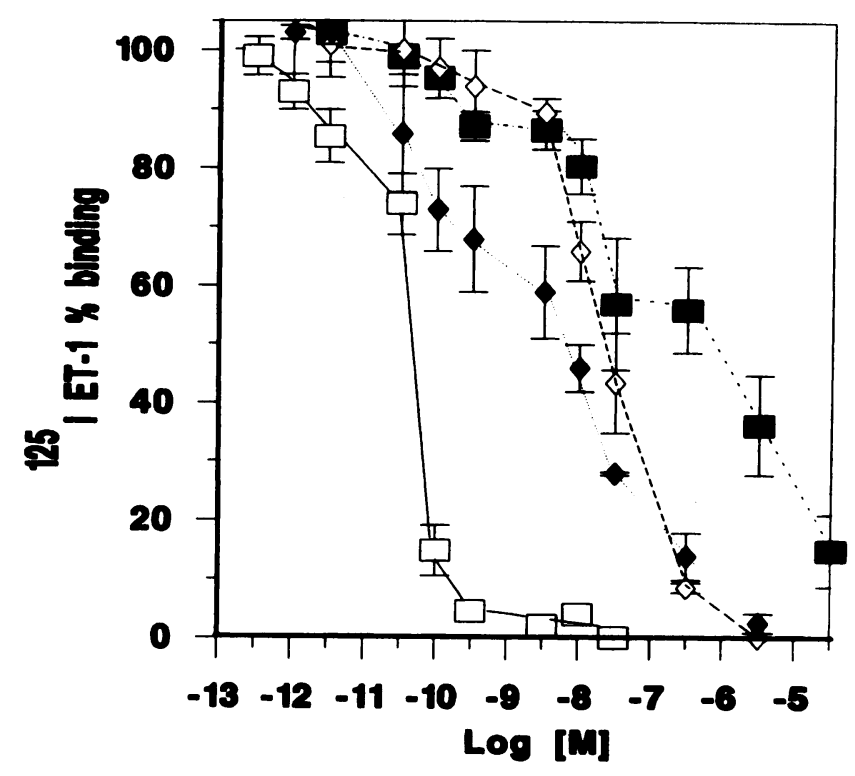

Figure 1. ${ }^{125} \mathrm{I}$ ET-1 displacement experiments by unlabeled ET-1 $(\square)$, ET-3 $(\diamond)$, BQ123 ( () , and safarotoxin S6C $(\diamond)$ in five normal human adrenal cortices. It is evident that ET-1 was the most potent in displacing ${ }^{125}$ I ET-1, followed by Sarafotoxin $6 \mathrm{C}$ (S $6 \mathrm{C}$ ), ET-3 and BQ123. Note that curves for (S 6 C) and BQ123 are biphasic, suggesting two binding sites.

phoresis followed by Southern vacuum blotting (LKB, Pharmacia) onto a nylon membrane. To further evaluate the kinetic of the amplification reaction slot blot analysis was carried out with a commercially available apparatus (Milliblot, Millipore, Milano, Italy). The PCR products transferred on a nylon membrane (Zeta-Probe GT; Biorad Laboratories, Milano, Italy) were UV cross-linked (Stratagene UV-Crosslinker 1800; Stratagene-Duotech Milano, Italy). Detection of the digoxigenin-labeled amplification products on the nylon membrane was carried out by a high affinity antidigoxigenin-antibody Fab-fragments conjugated to alkaline phosphatase using a chemiluminescent detection kit (DIG; Boehringer Mannheim, Germany). Light generated via dephosphorilation of the chemiluniscent substrate was used to impress XAR x-ray (Eastman Kodak Co., Rochester, NY) films with a 20-min exposure, as in an autoradiographic procedure. Quantification of the PCR products was carried out by measuring the integrated optical density of the autoradiographies with an image analyzer IBAS 2000 (Zeiss, Unterkochen, Germany). Plots of the log integrated optycal density vs number of cycles were then elaborated; the cycle number $\left(\mathrm{N}_{50}\right)$ that corresponded to the half-maximal PCR products was also calculated, as an estimate of the relative amounts of initial amplifiable template of the $\beta$-actin, $\mathrm{ET}_{\mathrm{A}}$, and $\mathrm{ET}_{\mathrm{B}}$ genes (40).

Autoradiography. Two normal adrenal cortices (including the capsule) and one APA immediately frozen in isopentane cooled in liquid nitrogen in the operating room were studied. Frozen $10-15-\mu \mathrm{m}$ sections were cut in a cryostat (Leitz 1720 Digital; Leitz, Wetzlar, Germany) at $-20^{\circ} \mathrm{C}$, and processed according to Kuhar (41) and Palacios et al. (42). Sections were preincubated in Tris- $\mathrm{HCl} 50 \mathrm{mM}$, pH 7.4, containing $0.01 \%$ bacitracine, $135 \mathrm{mM} \mathrm{NaCl}, 10 \mathrm{mM} \mathrm{MgCl}, 1 \mathrm{mM}$ tetrasodic EDTA, $0.2 \% \mathrm{BSA}$, for $15 \mathrm{~min}$ at $20^{\circ} \mathrm{C}$. ET-1 binding sites were labeled in vitro by incubation for 120 min with 100 pM ${ }^{125}$ I ET-1 (Amersham Laboratories, Amersham, Buckinghamshire, U.K.; specific activity $2,000 \mathrm{Ci} / \mathrm{mmol})$ at room temperature; nonspecific binding was determined by adding $1 \mu \mathrm{M}$ cold ET-1. Selective displacement of ${ }^{125}$ I ET-1 was studied by adding $500 \mathrm{nM}$ BQ-123 or $100 \mathrm{nM}$ sarafotoxin $6 \mathrm{C}$. Reaction was terminated by washing three times the samples in $50 \mathrm{nM}$ Tris- $\mathrm{HCl}$ buffer. After rinsing in distilled water, the sections were rapidly dried, fixed in paraformaldehyde vapors at $80^{\circ} \mathrm{C}$ for $120 \mathrm{~min}$, and then coated with NTB2 Kodak Nuclear emulsion (Eastman Kodak Co.).
Table I. Hill (for ET-1) or Pseudo-Hill Coefficients (nH) (for ET3, Sarafotoxin $6 C\left[\begin{array}{ll}S & 6 \\ C\end{array}\right]$ and BQ123), F-Ratio and Significance of the Two-vs One-Site Model Fitting in the Normal Human Adrenal Cortex

\begin{tabular}{lcccccc}
\hline & $n$ & $\mathrm{nH}$ & F-ratio & Significance & $\mathrm{ET}_{\mathrm{A}}$ & $\mathrm{ET}_{\mathrm{B}}$ \\
\hline & & & & & $n M$ & $n M$ \\
ET-1 & 6 & $0.74 \pm 0.06$ & 4.75 & $P=0.033$ & $0.047 \pm 0.006$ & $400 \pm 50$ \\
ET-3 & 5 & $0.56 \pm 0.16$ & 2.84 & $P=0.022$ & $47 \pm 52.6$ & $0.46 \pm 0.005$ \\
S 6 C & 3 & $0.47 \pm 0.19$ & 5.7 & $P=0.009$ & $33.0 \pm 41$ & $0.88 \pm 0.42$ \\
BQ123 & 4 & $0.37 \pm 0.05$ & 5.36 & $P=0.027$ & $5.5 \pm 0.45$ & $426 \pm 383$
\end{tabular}

$K_{\mathrm{d}}=$ Dissociation Constant values for ET-1, ET-3, S 6 C, and BQ123.

The autoradiograms were exposed for $2 \mathrm{wk}$ at $4^{\circ} \mathrm{C}$, and then developed with undiluted D19 Kodak developer. They were stained with hematoxylin-eosin, and observed and photographed with a Leitz Laborlux microscope.

Statistical analysis. Mean \pm SEM are used to report the results. Comparison between groups was performed by Student's $t$ test for unpaired data and Mann-Whitney non-parametric test (43). Statistical analysis was performed with SPSS/PC+ statistical package (SPSS Inc, Chicago, IL).

\section{Results}

${ }^{125}$ I ET-1 displacement binding. The results of the ${ }^{125}$ I ET-1 displacement studies from the five normal human adrenal cortices are shown in Fig. 1. Cold ET-1 was the most potent in displacing ${ }^{125}$ I ET-1 followed by S6C, ET-3, and BQ123. As it can be seen, both S6C and BQ123 produced biphasic competition binding curves, suggesting the presence of two binding sites. Analysis of the saturation and displacement experiments showed Hill and pseudo-Hill coefficient values less than unity for all ligands, suggesting the presence of multiple binding sites (Table I). Further analysis with the nonlinear curve-fitting program LIGAND revealed that the best fitting was provided by a two-site model, as shown by the significant values of the Fratio (Table I) (32). Simultaneous analysis of the results of the ${ }^{125}$ I ET-1 binding displacement with ET-1, S6C and BQ123 using the LIGAND subroutine again showed that a two-site model provided the best fitting of the experimental data $(F-$ ratio $22.07, P<0.0001$ ). The estimated $K_{\mathrm{d}}$ and $\mathrm{B}_{\max }$ values are shown in Table $I$; they resulted to be within the ranges that have been reported for the human myocardium by Molenaar et al. (44) with a sophisticate quantitative autoradiographic technique. The specific $\mathrm{ET}_{\mathrm{A}}$ antagonist $\mathrm{BQ} 123$ did not allow to displace ${ }^{125}$ I ET-1 completely, even at the highest concentration of $100 \mu \mathrm{M}$ that was used. Similar biphasic displacement curves and curvilinear Hofstee plots were obtained in the pt with APA, thereby suggesting the presence of two classes of ET-1 receptors also in this tissue. This was further confirmed by the significant value of the F-ratio ( $\mathrm{F}=18.42, P<0.0001)$, by the results of RT-PCR (Fig. $2 B$, see below) and the autoradiographic findings (see Fig. 6, and below). Estimated $B_{\max }$ were lower ( 1.33 and $0.8 \mathrm{pmol} / \mathrm{mg}$ protein), whereas the $K_{\mathrm{d}}$ were identical to those of Table I.

PCR results. The RT-PCR consistently allowed detection of the ET-1, $\mathrm{ET}_{\mathrm{A}}$, and $\mathrm{ET}_{\mathrm{B}} \mathrm{mRNA}$ in all adrenal specimen examined. An example of an $\mathrm{EtBr}$ stained $1.5 \%$ agarose gel is shown in Fig. 2. As it can be seen, amplified cDNA fragments 

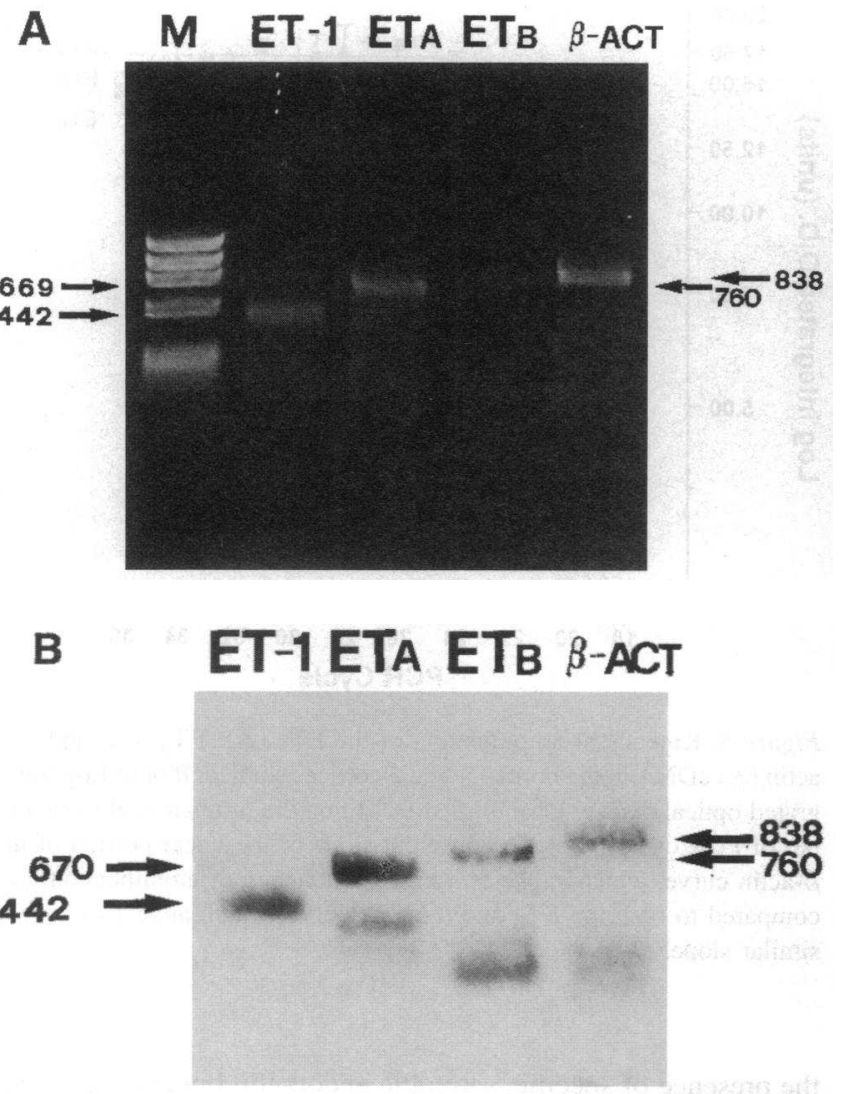

Figure 2. (A) $1.5 \%$ agarose gel showing cDNA amplified with ET-1, and with $\mathrm{ET}_{\mathrm{A}}$ and $\mathrm{ET}_{\mathrm{B}}$ receptor specific primers from a normal human adrenal cortex. Lane 1 was loaded with $200 \mathrm{ng}$ of a size marker (PhiX174 Hae III). The amplified fragments resulted to be of the expected size, which was 442,669 , and 760 bp for the ET-1, ET $\mathrm{A}_{\mathrm{A}}$, and $\mathrm{ET}_{\mathrm{B}}$, respectively. Amplification of a 838-bp fragment of the $\beta$-actin cDNA, as a positive control, is also shown. $(B)$ Southern blot of the same agarose gel after chemiluminescent detection demonstrates the absence of nonspecific products, which could have been anticipated given the $70 \%$ homology between the $\mathrm{ET}_{\mathrm{A}}$ and $\mathrm{ET}_{\mathrm{B}}$ receptor subtypes cDNAs.

of the expected size for both the $\mathrm{ET}_{\mathrm{A}}$ and $\mathrm{ET}_{\mathrm{B}}$ receptors and for the control $\beta$-actin gene were easily detected, both in the normal adrenals (Fig. $3 A$ ) and in the APA tissue (Fig. $3 B$ ). In the latter, a notable difference is evident in the expression of the $\mathrm{ET}_{\mathrm{A}}$ and $\mathrm{ET}_{\mathrm{B}}$ receptor between both normal and adenomatous adrenal cortex tissue and the renal cortex, despite no evident difference in the expression of the $\beta$-actin gene. No amplification was seen in the control PCR containing either no cDNA (water) or total RNA with no prior reverse transcription, thereby ruling out the possibility of false positive results and of amplification of genomic DNA, respectively (Fig. 3).

An x-ray film of a slot-blot containing the amplification products of different PCR cycles from two of the five normal adrenal cortices is shown in Fig. 4. The kinetics of amplification of the $\mathrm{ET}_{\mathrm{A}}$, the $\mathrm{ET}_{\mathrm{B}}$ and the $\beta$-actin cDNA is reported in Fig. 5 , where the log of integrated OD of amplified DNA is plotted vs number of PCR cycles. The $\mathrm{ET}_{\mathrm{A}}$ curve is shifted to the right as compared with the others; the slopes of the $\mathrm{ET}_{\mathrm{A}}$ and $\mathrm{ET}_{\mathrm{B}}$ amplification are similar, thereby suggesting a similar efficiency of amplification (40). The $\mathrm{N}_{50}$, i.e., the number of cycles at which half-maximal amplification was attained, resulted to be significantly lower $(P<0.05)$ for $\mathrm{ET}_{\mathrm{B}}(22.56 \pm 1.53)$ than for
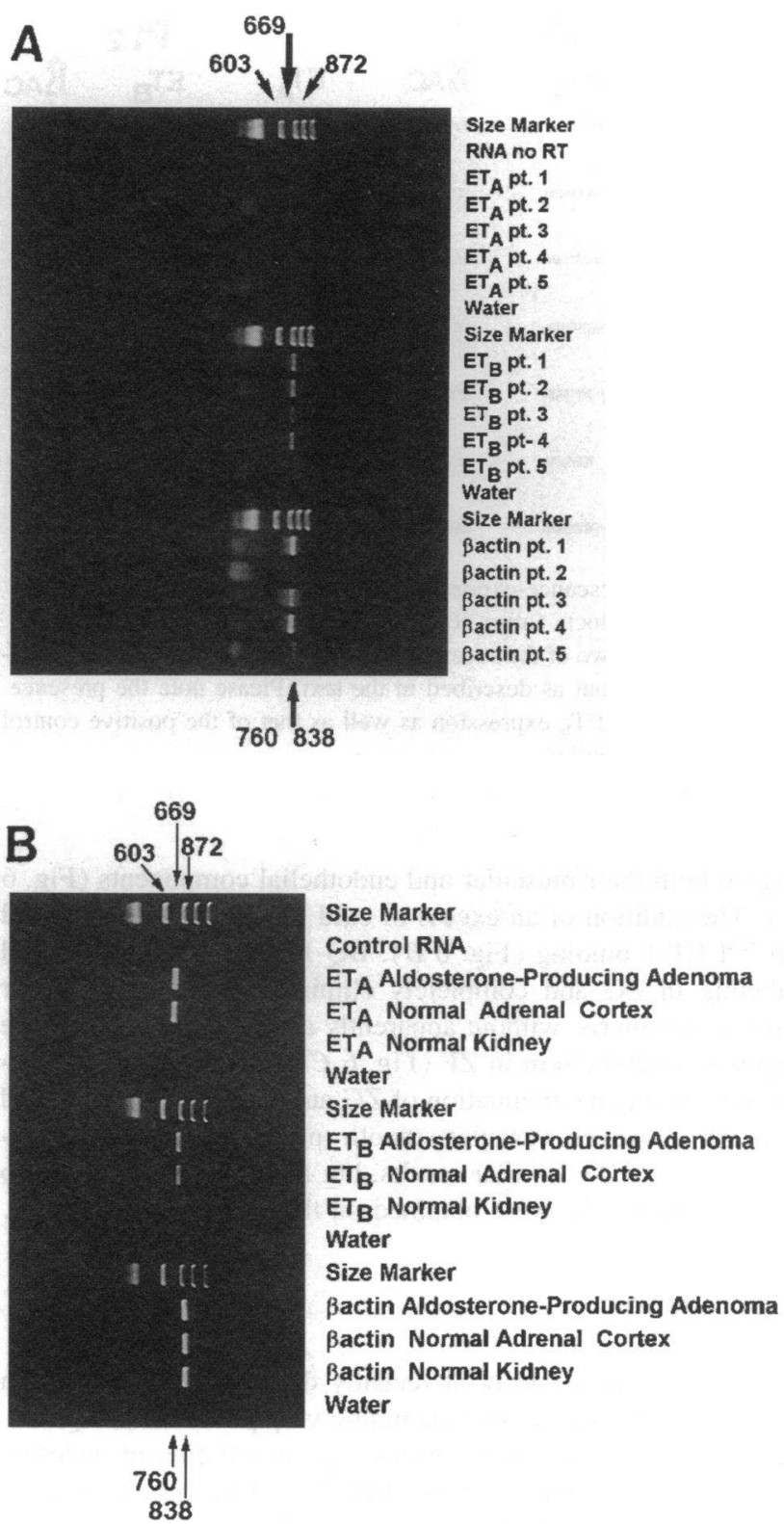

Figure 3. (A) Agarose gel showing cDNA amplified with $\mathrm{ET}_{\mathrm{A}}$ and $\mathrm{ET}_{\mathrm{B}}$ receptor-specific primers from five different normal human adrenal cortices. The amplified fragments resulted to be of the expected size, which was 669 and $760 \mathrm{bp}$ for the $\mathrm{ET}_{\mathrm{A}}$ and $\mathrm{ET}_{\mathrm{B}}$, respectively. Amplification of a 838-bp fragment of the $\beta$ actin cDNA, as a positive control, and lack of amplification with no DNA template, as a negative control, are also shown. Amplification of RNA with no prior reverse transcription (RNA no RT) is also shown in lane 2. (B) Agarose gel showing CDNA amplified with $\mathrm{ET}_{\mathrm{A}}$ and $\mathrm{ET}_{\mathrm{B}}$ receptor-specific primers from an aldosterone-producing adenoma, the surrounding histologically normal adrenal cortex and a kidney biopsy. Amplification of the $\beta$-actin cDNA, as a positive control, and lack of amplification with no DNA template, as a negative control, are also shown.

$\mathrm{ET}_{\mathrm{A}}(26.66 \pm 0.74)$, and might suggest a lower initial abundance of $\mathrm{ET}_{\mathrm{A}}$ mRNA (40).

Autoradiography findings. ${ }^{125} \mathrm{I}$ ET-1 binding was intense in the subcapsular ZG, while in the zona fasciculata it was very weak and clearly confined to the capillaries running between adjacent parenchymal cords. Adrenal capsule was not labeled, whereas extracapsular vessels displayed evident ${ }^{125}$ I ET-1 bind- 


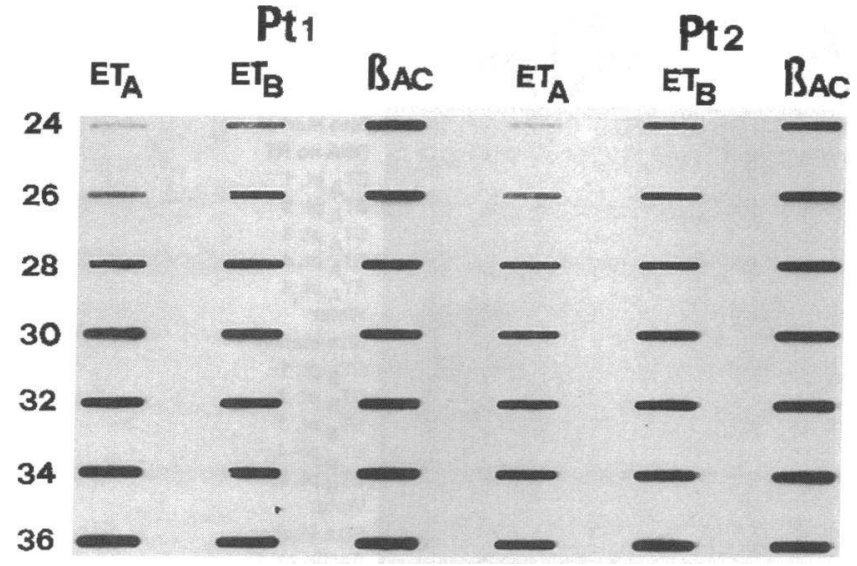

Figure 4. Luminescence-exposed $\mathrm{x}$-ray film of a slot-blot containing the RT-PCR products (after 36 cycles) of the $\mathrm{ET}_{\mathrm{A}}$ and $\mathrm{ET}_{\mathrm{B}}$, and the $\beta$-actin genes in two of the seven normal adrenal cortices studied. Detection was carried out as described in the text. Please note the presence of both $\mathrm{ET}_{\mathrm{A}}$ and $\mathrm{ET}_{\mathrm{B}}$ expression as well as that of the positive control $\beta$ actin in the samples.

ing on both their muscular and endothelial components (Fig. 6 $A)$. The addition of an excess of cold ET-1 virtually displaced all ${ }^{125}$ I ET-1 binding (Fig. $6 \mathrm{~B}$ ). BQ-123 markedly attenuated labeling in ZG and completely eliminated it in the vascular tunica muscularis, without apparently affecting ${ }^{125} \mathrm{I}$ ET-1 of the capillary endothelium in ZF (Fig. $6 \mathrm{C}$ ). Sarafotoxin $6 \mathrm{C}$ determined a moderate attenuation of ZG and completely eliminated it in ZF; however, vascular smooth muscle cells were still labeled (Fig. $6 \mathrm{D}$ ). Similar results, but a less intense binding to parenchymal cells, were obtained on the APA tissue (Fig. 7).

\section{Discussion}

Endothelins are a family of recently discovered peptides with multiple biological actions, including very potent and long-lasting vasoconstriction, mitogenesis, and stimulation of endothelium-derived relaxing factors (EDRFs), ANP, renin, argininvasopressin, and aldosterone release $(45,46)$. In anesthetized dogs the infusion of endothelin, aside from widespread hemodynamic effects, consistently induced a two-four-fold long-lasting increase of aldosterone secretion, as well as an increase of plasma renin activity (4). However, the stimulation of aldosterone secretion appeared to be independent of the renin-angiotensin system, since it was observed also in vitro in dispersed ZG cells $(2,3,11)$, and even after pretreatment with the angiotensin converting enzyme inhibitor captopril (46). Further studies have indeed shown that ET-1 directly stimulates aldosterone secretion, although less potently than angiotensin II, via a $\mathrm{Ca}^{2+}$. dependent mechanism $(7,47)$. This stimulation is deemed to involve enhancement of the synthesis of prostaglandins, since in perfused slices of frog adrenal gland it was associated with a release of prostaglandins and was abolished by indomethacin (7). In addition, ET-1 potentiates the aldosterone response to angiotensin II and ACTH $(8,9)$, possibly via an interaction with different receptor subtypes (26). Of interest, ACTH has been found to increase the release of endothelin-1 from the adrenals thereby suggesting that ET-1 is a mediator of ACTHstimulated aldosterone secretion (48). In vitro binding experiments on calf adrenal cultured glomerulosa cells have shown

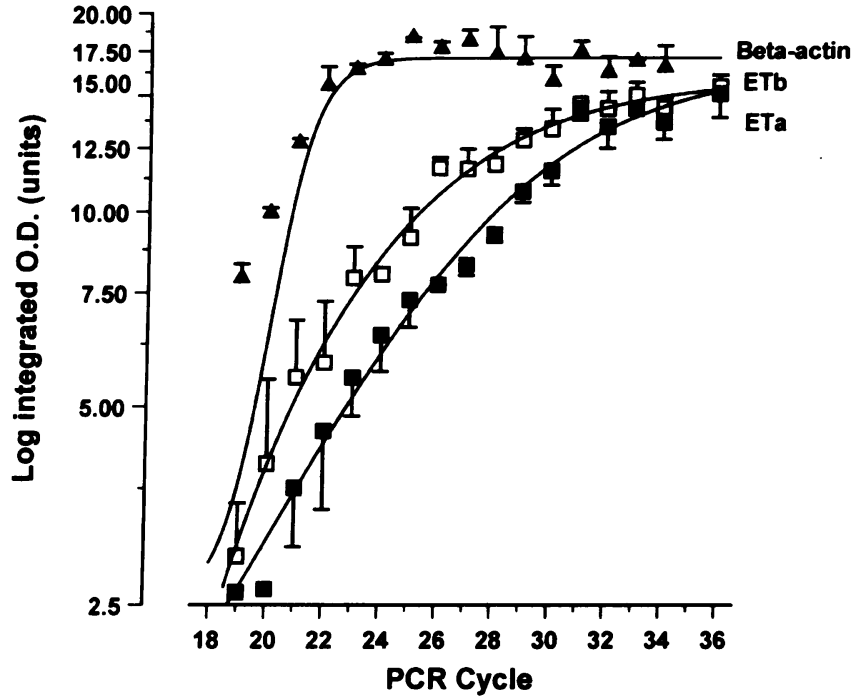

Figure 5. Kinetics of amplification of the $\mathrm{ET}_{\mathrm{A}}(\square), \mathrm{ET}_{\mathrm{B}} \cdot(\square)$ and $\beta$ actin $(\Delta)$ cDNA in the normal adrenal cortices studied. Plot of Log (integrated optical density of amplified DNA) on the ordinate scale vs number of PCR cycles. Note the different slope of the linear portion of the $\beta$-actin curve, which suggests a higher efficiency of amplification, as compared to both the $\mathrm{ET}_{\mathrm{A}}$ and the $\mathrm{ET}_{\mathrm{B}}$ curve, which appear to have a similar slope.

the presence of specific, saturable endothelin binding sites with an average $K_{\mathrm{d}}$ of $0.086 \mathrm{nM}(2)$. However, this was not a proof of the existence of only a single class of ET-1 receptors, given the selectivity ratio of ET-1 for the two identified receptors $\mathrm{ET}_{\mathrm{A}}$ and $\mathrm{ET}_{\mathrm{B}}$ and their similar relative densities. Therefore, no conclusion could be made based on ET-1 saturation binding isotherms alone $(32,33)$. Further studies on the same experimental model with the endothelin analogue sarafotoxin $6 \mathrm{~B}$, which was equipotent to ET-1 in stimulating aldosterone secretion, and with ET-3, a very poor stimulator of aldosterone secretion, have thereafter suggested the presence of two different endothelin receptors; a high-affinity ( $K_{\mathrm{d}}$ of $\left.0.05 \mathrm{nM}\right)$ and a low-affinity $\left(K_{\mathrm{d}}\right.$ of $\left.0.17 \mathrm{nM}\right)$ receptor $(26)$. Our study takes advantage of two facts: the recent identification and cloning of two human endothelin receptors $(38,39,49)$ and the development of specific antagonists for each one of them $(29,50)$. The isopeptide-selective $\mathrm{ET}_{\mathrm{A}}$ receptor, identified from a human cDNA library $(21,38)$ preferentially binds ET- 1 and is specifically antagonised by BQ123. Its mRNA has been detected in the central nervous system as well as in the aorta, heart and lung (21). At variance, the nonisopeptide-selective $\mathrm{ET}_{\mathrm{B}}$ was found to bind ET-1, ET-2, and ET-3 with the same affinity and to be antagonised by S6C $(29,51)$. It is considered to be present on endothelial cells where it can mediate the release of EDRFs (50), but also on vascular and nonvascular smooth muscle cells (52).

The results of this study show that these two endothelin receptors are expressed in the human adrenal cortex as transcription and translation products. ${ }^{125}$ I ET-1 displacement binding curves carried out in these extracts with ET-1, ET-3, and with $\mathrm{BQ} 123$ and S6C, two selective antagonists for the $\mathrm{ET}_{\mathrm{A}}$ and $\mathrm{ET}_{\mathrm{B}}$ receptor, revealed Hill and pseudo-Hill coefficients less than unity (Table I), indicating multiple binding sites. Furthermore, coanalysis of the binding curves obtained with the different agonists and antagonists showed that the best fitting of the 

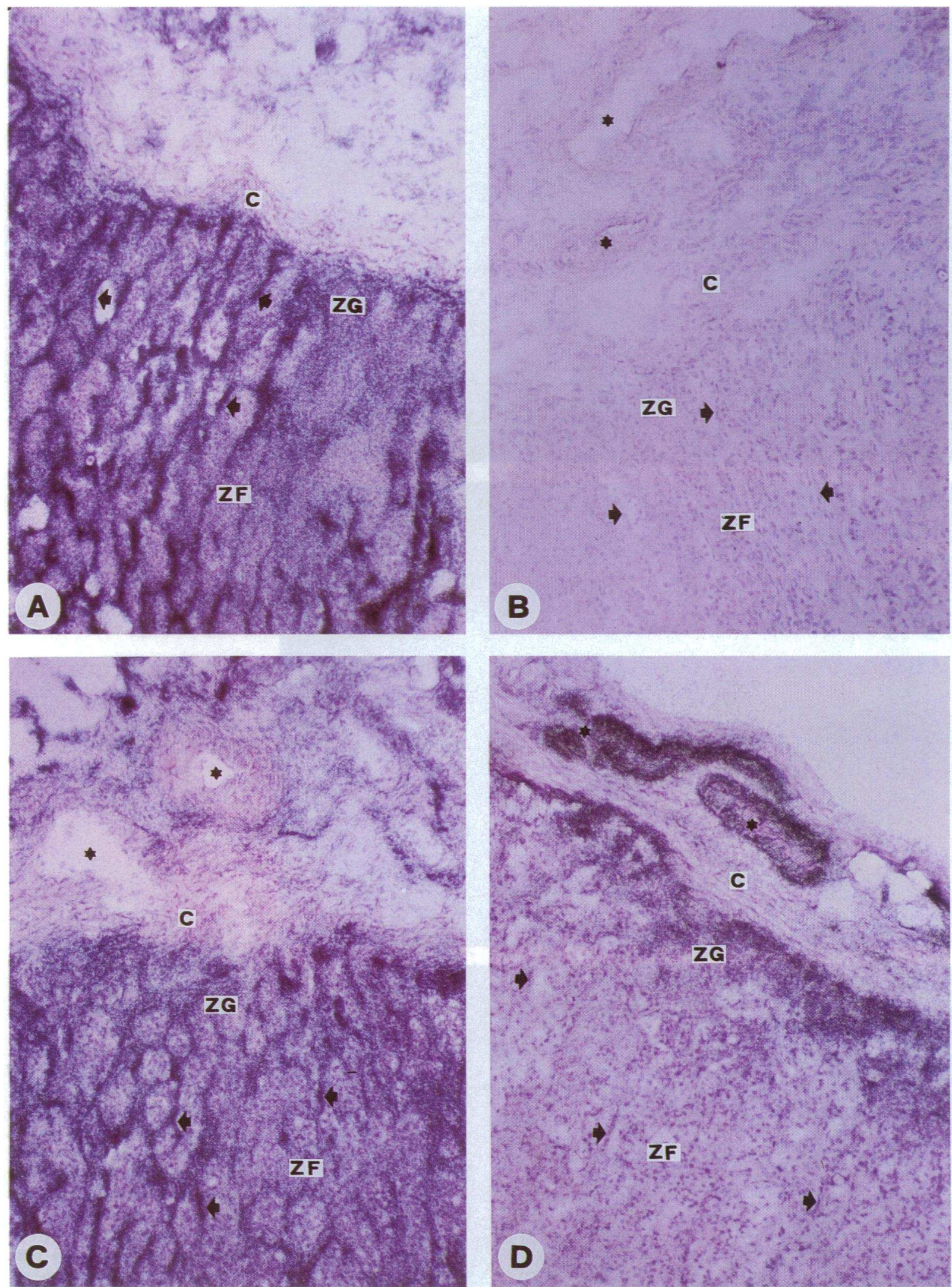

Figure 6. Autoradiographs of frozen sections of human adrenal glands incubated with ${ }^{125} \mathrm{I}-\mathrm{ET}-1$ ( $\left.100 \mathrm{pM}\right)$. (A) Binding is well distributed and more intense to the zona glomerulosa $(Z G)$ than to the zona fasciculata $(Z F)$, where it is mainly located on the capillaries running among the parenchymal cords. $(B)$ ${ }^{125}$ I ET-1 is completely displaced by the addition of a 1- $\mu \mathrm{M}$ cold ET-1. (C) BQ-123 slightly attenuates binding to the ZG cells, while it does not affect labelling to endothelium of the capillaries of ZF; in addition, it completely displaces ${ }^{125} \mathrm{I}$ ET-1 binding to the tunica media of the arterioles (asterisks) in the capsule $(C)$. (D) Sarafotoxin $6 \mathrm{C}$ attenuates ${ }^{125}$ I ET-1 binding to ZG cells while it eliminates that to the endothelium (arrows) of capillaries in ZF; the binding to the muscular wall of capsular arterioles is not affected. $C$ gland capsule, *lumen of extracapsular vessels. Magnification $\times 140$ for all sections. 

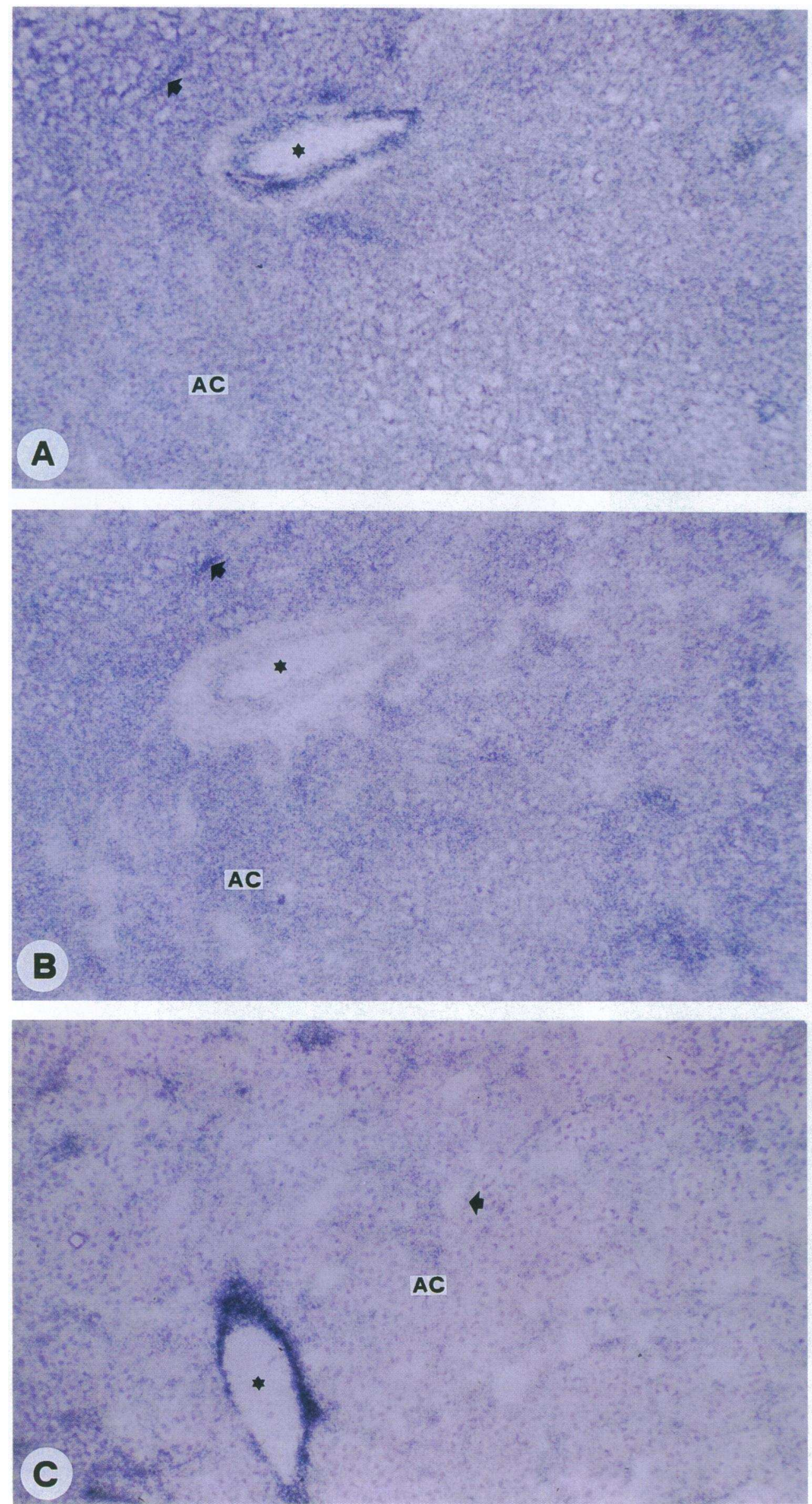

Figure 7. Autoradiographs of frozen sections of an aldosteroneproducing adenoma incubated with ${ }^{125}$ I ET-1 ( 100 pM). (A) Total binding. A diffuse binding to APA cells as well as a more intense binding to an arteriolar wall (asterisks) is evident. (B) BQ$123(500 \mathrm{nM})$ displaces ${ }^{125} \mathrm{I}$ ET-1 binding to the tunica media of an arteriole (asterisk) without affecting that to the endothelium of the same vessel and of the capillaries (arrow). (C) Sarafotoxin 6C (100 nM) attenuates ${ }^{125}$ I ET-1 binding to the adenomatous cells $(A C)$ and even more so to the endothelial lining of capillaries (arrow). The ${ }^{125}$ I ET-1 binding to the tunica media of an arteriole (asterisk) persist unaffected. AC, APA cells. *Lumen of an arteriole. Magnification $\times 145$ for all sections. 
experimental data was provided by a two-site model (Table I). Thus, our results demonstrate the presence of two endothelin receptor subtypes. Their respective $K_{\mathrm{d}}$ values appear to be closer than those found by Molenaar et al. (44) with a quantitative autoradiography technique in the human myocardium and atrioventricular conducting tissue. However, experiments with mammalian cells transfected with cloned cDNAs of the human $\mathrm{ET}_{\mathrm{A}}$ and $\mathrm{ET}_{\mathrm{B}}$ receptors, reported even closer values for the two receptor subtypes (53-54). The reasons for these discrepancies are at present unclear, but might relate to the different experimental conditions used in the different studies, which may alter the accessibility of ET-1 to its receptors.

With the use of specific primers we have been able to amplify the cDNA of ET-1, $\mathrm{ET}_{\mathrm{A}}$, and $\mathrm{ET}_{\mathrm{B}}$ genes after reversetranscription from total RNA by the random hexamers method. Indeed, this approach has consistently allowed the amplification of cDNA fragments of the expected size for each one of the genes in all specimen tested. In this study the $\mathrm{ET}_{\mathrm{A}}$ and $\mathrm{ET}_{\mathrm{B}}$ mRNA was reverse-transcribed in the same reaction tube, thereby eliminating the reverse transcription step as a source of variability in gene dosage. Investigation of the kinetics of PCR amplification was shown to be valuable for the comparison of the expression of different genes whenever the efficiency of the amplification is similar (40). The results of Fig. 5 and the fact that the $\mathrm{N}_{50}$ of $\mathrm{ET}_{\mathrm{B}}$ was significantly lower than that of $\mathrm{ET}_{\mathrm{A}}$ might suggest a higher initial abundance of mRNA of the former receptor. However, several factors, including small differencies of amplification efficiency, different length and thymidine content of the amplification products, lack of a deletion/insertion mutant as an internal standard, and the topographical location of the specimen used, may affect this conclusion.

To obtain a more precise anatomical location of the receptor subtypes, we performed autoradiography with ${ }^{125}$ I ET-1 in the presence and in the absence of BQ-123 and sarafotoxin $6 \mathrm{C}$. The results of these experiments provide, to the best of our knowledge, the first evidence of the existence of both receptor subtypes in the human ZG (Fig. 6). They also confirmed the expected distribution of the $\mathrm{ET}_{\mathrm{A}}$ and $\mathrm{ET}_{\mathrm{B}}$ subtype on the arteriolar tunica media and the endothelial lining of the sinusoids, respectively (Figs. 6 and 7). An intense ET-1 binding was previously detected in the subcapsular lining of the rat adrenal cortex at autoradiography $(22,25)$, and also in dispersed ZG cells in vitro (2). However, the heterogeneity of distribution of the two receptor subtypes in the different zones and structures of the adrenal cortex found in our study has some relevant implications for both the genes expression and the binding experiments studies. They were carried out on tissue homogenates and therefore are likely to be critically dependent on the topographical location of the tissue section investigated. Consequently, whilst they clearly show the presence of both ET-1 and its $\mathrm{ET}_{\mathrm{A}}$ and $\mathrm{ET}_{\mathrm{B}}$ receptor subtypes, no conclusive information on their relative amounts on ZG cells can be gained by such experiments. Obviously, different methodologies, such as quantitative autoradiography, in situ PCR, and/or experiments with cultured ZG cells, are required to address this question.

Nevertheless, taken altogether our results demonstrate that both the ET-1 and its $\mathrm{ET}_{\mathrm{A}}$ and $\mathrm{ET}_{\mathrm{B}}$ receptor subtypes genes are transcribed and translated into protein in the adrenal cortex, as well as in a tumor that is histogenetically derived from the ZG cells. It is additionally shown that the level of transcripts of both receptors was higher in the adrenal than in the renal cortex of the same patient with APA (Fig. $3 B$ ), a finding that support the concept of a major role of ET-1 in the paracrine regulation of aldosterone secretion. This role is further underlined by at least two sets of evidence: first, ZG cells appear to be able to distinguish between the stimulation of phosphatidylinositol turnover induced by ET-1 and those triggered by angiotensin II and vasopressin (47); second, ET-1 is capable of downregulating its receptors by enhancing internalisation of the hormonereceptor complex (55).

A final comment deserves our finding that both the $\mathrm{ET}_{\mathrm{A}}$ and $\mathrm{ET}_{\mathrm{B}}$ receptor subtypes were detected in an APA, as well as in the surrounding histologically normal cortex, at the level of gene expression and also with ${ }^{125}$ I ET-1 displacement binding and autoradiography experiments (Fig. 7). Of interest, in five patients with primary aldosteronism Zeng et al. (56) reported that endothelin stimulated the secretion of aldosterone in vitro from the cortex surrounding aldosterone-producing adenomas in a dose-dependent fashion, but not from the tumors: Although further studies are needed before drawing more definitive conclusions, our experiments provide evidence that the mRNAs for both the $\mathrm{ET}_{\mathrm{A}}$ and $\mathrm{ET}_{\mathrm{B}}$ receptor subtypes are detectable and that these receptors can be functionally measured in the APA tissue. In addition, lower $B_{\max }$ values of both receptor subtypes and a less intense ${ }^{125}$ I ET-1 binding at autoradiography (Fig. 7) were observed in the APA tissue. Accordingly, these findings may suggest that the absence of aldosterone response in vitro to ET1 is not due to lack of expression of the genes encoding for the two ET-1 receptor subtypes, but may rather be ascribed to a decreased rate of transcription resulting in a lower density of the density of both receptors in the tumor tissue as compared to the normal adrenal cortex.

\section{Acknowledgments}

This study was made possible by the precious collaboration of all our colleagues of the Departments of Urology (directed by Professor Francesco Pagano) and Surgical Pathology 1 (Prof. Maria Rosa Pelizzo) that we gratefully acknowledge.

This work was supported by The Italian National Research Council (CNR) - Targeted Project "Prevention and Control of Disease Factors (FATMA) ": Sub project “"8”' Contract N. 91.00.218 PF41 115.06.654 and by Regione Veneto, Giunta Regionale, Ricerca Finalizzata, Venezia, Italia.

\section{References}

1. Young, W. F., M. J. Hogan, G. G. Klee, C. S. Grant, and J. A. van Heerden. 1990. Primary aldosteronism: diagnosis and treatment. Mayo Clin. Proc. 65:96110.

2. Cozza, E. N., C. E. Gomez Sanchez, M. F. Foecking, and S. Chiou. 1989. Endothelin binding to cultured calf adrenal zona glomerulosa cells and stimulation of aldosterone secretion. J. Clin. Invest. 84:1032-1035.

3. Morishita, R., J. Higaki, and T. Ogihara. 1989. Endothelin stimulates aldosterone biosynthesis by dispersed rabbit adreno-capsular cells. Biochem. Biophys. Res. Commun. 160:628-632.

4. Miller, W. L., M. M. Redfield, and J. C. J. Burnett. 1989. Integrated cardiac, renal, and endocrine actions of endothelin. J. Clin. Invest. 83:317-320.

5. Nakamoto, H., H. Suzuki, M. Murakami, Y. Kageyama, A. Ohishi, K. Fukuda, S. Hori, and T. Saruta. 1989. Effects of endothelin on systemic and renal haemodynamics and neuroendocrine hormones in conscious dogs. Clin. Sci. 77:567-572.

6. Hinson, J. P., S. Kapas, R. Teja, and G. P. Vinson. 1991. Effect of the endothelins on aldosterone secretion by rat zona glomerulosa cells in vitro. $J$. Steroid Biochem. Mol. Biol. 40:437-439.

7. Delarue, C., I. Delton, F. Fiorini, F. Homo Delarche, A. Fasolo, P. Braquet, and H. Vaudry. 1990. Endothelin stimulates steroid secretion by frog adrenal gland in vitro: evidence for the involvement of prostaglandins and extracellular calcium in the mechanism of actin of endothelin. Endocrinology. 127:2001-2008.

8. Cozza, E. N., S. Chiou, and C. E. Gomez Sanchez. 1992. Endothelin-1 potentiation of angiotensin II stimulation of aldosterone production. Am. J. Physiol. 262:R85-R89. 
9. Rosolowsky, L. J., and W. B. Campbell. 1990. Endothelin enhances adrenocorticotropin-stimulated aldosterone release from cultured bovine adrenal cells. Endocrinology. 126:1860-1866.

10. Mazzocchi, G., P. Rebuffat, V. Meneghelli, L. K. Malendowicz, A. Kasprzak, and G. G. Nussdorfer. 1990. Effects of prolonged infusion with endothelin1 on the function and morphology of rat adrenal cortex. Peptides. 11:767-772.

11. Mazzocchi, G., L. K. Malendowicz, and G. G. Nussdorfer. 1990. Endothelin-1 acutely stimulates the secretory activity of rat zona glomerulosa cells. Peptides. 11:763-765.

12. Uchihara, M., N. Izumi, C. Sato, and F. Marumo. 1992. Clinical significance of elevated plasma endothelin concentration in patients with cirrhosis. Hepatology. 16:95-99.

13. Stewart, D. J., P. Cernacek, K. B. Costello, and J. L. Rouleau. 1992. Elevated endothelin-1 in heart failure and loss of normal response to postura change. Circulation. 85:510-517.

14. Hensen, J., B. Levenson, K. Schroder, M. Jereczek, C. Spielberg, K. Schwenn, and P. Gross. 1991. [Plasma endothelin is increased in heart failureno effect of a short infusion of atrial natriuretic factor]. Z. Kardiol. $80 \mathrm{Suppl}$ 8:101-102.

15. Clark, B. A., L. Halvorson, B. Sachs, and F. H. Epstein. 1992. Plasma endothelin levels in preeclampsia: elevation and correlation with uric acid levels and renal impairment. Am. J. Obstet. Gynecol. 66:962-968.

16. Textor, S. C, D. J. Wilson, A. Lerman, J. C. Romero, J. C. J. Burnett, R. Wiesner, E. R. Dickson, and R. A. Krom. 1992. Renal hemodynamics, urinary eicosanoids, and endothelin after liver transplantation. Transplantation. 54:7480 .

17. Lerman, A., R. L. Click, B. J. Narr, R. H. Wiesner, R. A. Krom, S. C. Textor, and J. C. J. Burnett. 1991. Elevation of plasma endothelin associated with systemic hypertension in humans following orthotopic liver transplantation. Transplantation. 51:646-650.

18. Nakamura, T., K. Kasai, Y. Sekiguchi, N. Banba, K. Takahashi, T. Emoto, Y. Hattori, and S. Shimoda. Elevation of plasma endothelin concentrations during endotoxin shock in dogs. Eur. J. Pharmacol. 1991. 205:277-282.

19. Widimsky, J. J., K. Horky, and J. Dvorakova. 1991. Plasma endothelin1,2 levels in mild and severe hypertension. J. Hypertens. 9:S194-S195.

20. Shichiri, M., Y. Hirata, K. Ando, T. Emori, K. Ohta, S. Kimoto, M. Ogura, A. Inoue, and F. Marumo. 1990. Plasma endothelin levels in hypertension and chronic renal failure. Hypertension. 15:493-496.

21. Sakurai, T., M. Yanagisawa, M., and T. Masaki. 1992. Molecular characterization of endothelin receptors. TIPS. 13:103-108

22. Koseki, C., M. Imai, Y. Hirata, M. Yanagisawa, and T. Masaki. 1989. Autoradiographic distribution in rat tissues of binding sites for endothelin: a neuropeptide? Am. J. Physiol. 256:R858-R866.

23. Davenport, A. P., D. J. Nunez, J. A. Hall, A. J. Kaumann, and M. J. Brown. 1989. Autoradiographical localization of binding sites for porcine $\left[{ }^{125} \mathrm{I}\right]$ Endothelin-1 in humans, pigs and rats: functional relevance in humans. J. Cardiovasc. Pharmacol. 13(Suppl. 5):S166-S170.

24. Kohzuki, M., C. I. Johnston, S. Y. Chai, D. J. Casley, F. Rogerson, and F. A. Mendelsohn. 1989. Endothelin receptors in rat adrenal gland visualized by quantitative autoradiography. Clin. Exp. Pharmacol. Physiol. 16:239-242.

25. Kohzuki, M., C. I. Johnston, K. Abe, S. Y. Chai, D. J. Casley, M. Yasujima, K. Yoshinaga, and F. A. Mendelsohn. 1991. In vitro autoradiographic endothelin1 binding sites and sarafotoxin S6B binding sites in rat tissues. Clin. Exp. Pharmacol. Physiol. 18:509-515.

26. Gomez Sanchez, C. E., E. N. Cozza, M. F. Foecking, S. Chiou, and M. W. Ferris. 1990. Endothelin receptor subtypes and stimulation of aldosterone secretion. Hypertension. 15:744-747.

27. Imai, T., Y. Hirata, S. Eguchi, K. Kanno, K. Ohta, T. Emori, A. Sakamoto, M. Yanagisawa, T. Masaki, and F. Marumo. 1992. Concomitant expression of receptor subtype and isopeptide of endothelin by human adrenal gland. Biochem. Biophys. Res. Commun. 182:1115-1121.

28. Nguyen, P. V., A. Parent, L. Y. Deng, J. P. Flückiger, G. Thibault, and E. L. Schiffrin. 1992. Endothelin vascular receptors and responses in deoxycorticosterone acetate-salt hypertensive rats. Hypertension. 19(Suppl. II):II-98-II104.

29. Williams, D. L., K. L. Jones, D. J. Pettibone, E. V. Lis, and B. V. Clineschmidt. 1991. Sarafotoxin S6c: an agonist which distinguishes between endothelin receptor subtypes. Biochem. Biophys. Res. Commun. 175:556-561.

30. Clozel, M. 1989. Endothelin sensitivity and receptor binding in the aorta of spontaneously hypertensive rats. J. Hypertens. 7:913-917.

31. Zanin, L., G. P. Rossi, P. Pauletto, M. Tonello, G. Cargnelli, and A. C. Pessina. 1991. Decreased density of endothelin-1 binding sites in aortic smooth muscle cells of spontaneously hypertensive rats. J. Hypertens. 9(Suppl. 6):S190S191.

32. Munson, P. J., and D. Roadbard. 1980. Ligand: a versatile computerized approac.

33. Molinoff, P. B., B. B. Wolfe, and G. A. Weiland. 1981. Quantitative analysis of drug-receptor interactions: II determination of the properties of receptor subtypes. Life Sci. 29:427-443.

34. Doyle, V. M., F. R. Bühler, and E. Bürgisser. 1984. Inappropriate correction for radioactive decay in fully iodinated adrenergic radioligands. Eur. J. Pharmacol. 99:353-356.

35. Auffray, C., and F. Rougeon. 1980. Purification of mouse immunoglobulin heavy chain mRNAs from total myeloma tumour RNA. Eur. J. Biochem. 107:303314.

36. Wang, A. M., M. V. Doyle, and D. F. Mark. 1989. Quantification of mRNA by the polymerase chain reaction. Proc. Natl. Acad. Sci. USA. 86:97179721.

37. Inoue, A., M. Yanagisawa, Y. Takuwa, Y. Mitsui, M. Kobayashi, and T Masaki. 1989. The human preproendothelin-1 gene. J. Biol. Chem. 264:1495414959.

38. Hosoda, K., K. Nakao, H. Arai, S. Suga, Y. Ogawa, M. Mukoyama, G. Shirakami, Y. Saito, S. Nakanishi, and H. Imura. 1991. Cloning and expression of human endothelin-1 receptor cDNA. FEBS (Fed. Eur. Biochem. Soc.) Lett. 287:23-26.

39. Ogawa, Y., K. Nakao, H. Arai, O. Nakagawa, K. Hosoda, S. Suga, S. Nakanishi, and H. Imura. 1991. Molecular cloning of a non-isopeptide selective human endothelin receptor. Biochem. Biophys. Res. Commun. 178:248-255.

40. Trapnell, B. C. 1993. Quantitative evaluation of gene expression in freshly isolated human respiratory epithelial cells. Am. J. Physiol. 264:L199-L212.

41. Kuhar, M. J. 1985. Receptor localization with the microscope. In Neurotransmitter Receptor Binding. H. I. Yamamura, S. J. Enna, and M. J. Kuhar, editors. Raven Press, New York. 153-176.

42. Palacjos, J. M., R. Cortes, and M. M. Dietl. 1988. A laboratory guide for the in vitro labelling of receptors in tissue sections for autoradiography. In Molecular Neuroanatomy. F. W. Van Leeuwe, R. M. Buijs, C. W. Pool, and O. Pach, editors. Elsevier/North Holland, Amsterdam. 95-110.

43. Rosner, B. 1986. Fundamentals of biostatistics. Duxbury Press, Boston.

44. Molenaar, P., G. O'Reilly, A. Sharkey, R. E. Kuc, D. P. Harding, C. Plumpton, G. A. Gresham, and A. P. Davenport. 1993. Characterization and localization of endothelin receptor subtypes in the human atrioventricular conducting system and myocardium. Circ. Res. 72:526-538.

45. Yanagisawa, M., H. Kurihara, S. Kimura, Y. Tomobe, M. Kobayashi, Y. Mitsui, Y. Yazaki, K. Goto, and T. Masaki. 1988. A novel potent vasoconstrictor peptide produced by vascular endothelial cells. Nature (Lond.). 332:411-415.

46. Cao, L. Q., and R. O. Banks. 1990. Cardiorenal actions of endothelin Part I: effects of converting enzyme inhibition. Life Sci. 46:577-583.

47. Woodcock, E. A., J. K. Tanner, L. M. Caroccia, and P. J. Little. 1990 Mechanisms involved in the stimulation of aldosterone production by angiotensin II, vasopressin and endothelin. Clin. Exp. Pharmacol. Physiol. 17:263-267.

48. Hinson, J. P., G. P. Vinson, S. Kapas, and R. Teja. 1991. The role of endothelin in the control of adrenocortical function: stimulation of endothelin release by ACTH and the effects of endothelin- 1 and endothelin- 3 on steroidogenesis in rat and human adrenocortical cells. J. Endocrinol. 128:275-280.

49. Arai, H., K. Nakao, K. Takaya, K. Hosoda, Y. Ogawa, S. Nakanishi, and H. Imura 1993. The human endothelin-B gene. J. Biol. Chem. 268:3463-3470.

50. Ihara, M., K. Noguchi, T. Saeki, T. Fukuroda, S. Tsuchida, S. Kimura, T. Fukami, K. Ishikawa, M. Nishikibe, and M. Yano. 1992. Biological profiles of highly potent novel endothelin antagonists selective for the ETA receptor. Life Sci. 50:247-255.

51. Sakurai, T., M. Yanagisawa, Y. Takuwa, H. Miyazaki, S. Kimura, K Goto, and T. Masaki. 1990. Cloning of a cDNA encoding a non-isopeptideselective subtype of the endothelin receptor. Nature (Lond.). 348:732-735.

52. Hori, S., Y. Komatsu, R. Shigemoto, M. Mizuno, and S. Nakanishi. 1992. Distinct tissue distribution and cellular localization of two messenger ribonucleic acides encoding different subtypes of rat endothelin receptors. Endocrinology. 130:1885-1895.

53. Hechler, U., A. Becker, B. Haendler, and W. D. Schleuning. 1993. Stable expression of human endothelin receptors ETA and ETB by transfected baby hamster kidney cells. Biochem. Biophys. Res. Commun. 194:1305-1310.

54. Williams, D. L., K. L. Jones, K. Alves, C. P. Chan, G. F. Hollis, and J. S. Tung. 1993. Characterization of cloned human endothelin receptor. Life Sci. 53:407-414.

55. Cozza, E. N., and C. E. Gomez-Sanchez. 1990. Effects of endothelin-1 on its receptor concentration and thymidine incorporation in calf adrenal zona glomerulosa cells: a comparative study with phorbol esters. Endocrinology. 127:549-554.

56. Zeng, Z. P., M. Naruse, B. J. Guan, K. Naruse, M. L. Sun, M. F. Zang H. Demura, and Y. F. Shi. 1992. Endothelin stimulates aldosterone secretion in vitro from normal adrenocortical tissue, but not adenoma tissue, in primary ildosteronism. $J$. Clin. Endocrinol. Metab. 74:874-878. 